\title{
KUTOVI I POLUMJERI PROHODNOSTI SKIDERA S VITLOM
}

\section{MANEUVERABILITY CHARACTERISTICS OF CABLE SKIDDER}

\author{
Tomislav PORŠINSKY, Maja MORO, Andreja ĐUKA*
}

\begin{abstract}
Sažetak
Prohodnost šumskog vozila, određena je njegovom mogućnošću svladavanja terenskih nepravilnosti šumskoga bespuća, pri čemu dolazi do interakcije dva geometrijska sustava - geometrije vozila i geometrije površine terena. Sama se prohodnost vozila (kao sastavnica kretnosti) očituje kroz: 1) mogućnost kretanja vozila po nepravilnostima terena, 2) mogućnost upravljanja (kontrole) vozilom, ali i 3) udobnost vožnje.

Dimenzijske su značajke šumskih vozila određene tijekom njihove konstrukcije (gabaritne mjere, kretni sustav i način upravljanja, masa vozila i položaj točke težišta) te utječu na razinu njihove prohodnosti. Neovisno o namjeni vozila, poznati su mnogi pokazatelji njihove prohodnosti koji im određuju područje operativne primjene, a među koje se ubrajaju i kutovi te polumjeri prohodnosti vozila. Literatura poznaje navedene pokazatelje, ali i samo približno točne izraze za njihovo izračunavanje uslijed različitosti konstrukcije i primjene vozila uopće.

Rad se bavi, na primjeru skidera s vitlom, značenjem kutova i polumjera prohodnosti šumskih vozila, kao pokazateljima njihove prohodnosti pri kretanju po nepravilnostima šumskoga bespuća. Uvažavajući posebnosti konstrukcije skidera s vitlom te ustaljenost odnosa među dimenzijskim značajkama neovisno o njihovim proizvođačima, izvedeni su izrazi za: prednji, središnji i stražnji kut prohodnosti te uzdužni i poprečni polumjer prohodnosti skidera.
\end{abstract}

KLJUČNE RIJEČI: skider, prednji, središnji i stražnji kut prohodnosti, poprečni i uzdužni polumjer prohodnosti

\section{UVOD}

\section{INTRODUCTION}

Primjena šumskih vozila u mehaniziranim procesima proizvodnje drva predstavlja još uvjek najdjelotvorniji način pridobivanja drva (Heinimann 1995, Strandgard i dr. 2014, Visser i Berkett 2015, Visser i Stampfer 2015), pri čemu se pred šumska vozila postavlja zahtjev za njihovom što većom kretnošću u odnosu na prometnost terena šumskoga bespuća.

Prometnost je terena (eng. terrain trafficability) određena kao svojstvo terena da omogućuje prolazak (kretanje) vozila, pri čemu dolazi do izražaja utjecaj terenskih čimbenika (nagib terena, površinske prepreke i nosivost podloge) na kretnost vozila (Eichrodt i Heinimann 2001, Suvinen 2006). S druge strane, kretnost je šumskih vozila (eng. vehicle mobility) sposobnost prolaska vozila s jednoga na drugo mjesto u prostoru šumskoga radilišta (sječine) uz zadržavanje: 1) mogućnosti izvršavanja svoje primarne zadaće - sječe i izradbe i/ili privlačenja drva, 2) okolišne i energijske pogodnosti (Eichrodt 2003, Lubello 2008, Đuka 2014).

Pri pridobivanju drva, na za šumska vozila neprometnim terenima, njihovu kretnost osigurava gradnja mreže traktorskih putova (Enache i dr. 2015, Sabo i Poršinsky 2005), dok je u zadnjem desetljeću sve prisutnije opremanje šumskih vozila dodatnim vitlom, čije uže nema namjenu prihvata/sakupljanja drva, već sidrenja i/ili dodatne trakcije

\footnotetext{
1 Prof. dr. sc. Tomislav Poršinsky, e-pošta: porsinsky@sumfak.hr

* Dr. sc. Andreja Đuka, e-pošta: aduka@sumfak.hr

Zavod za šumarske tehnike i tehnologije, Šumarski fakultet Sveučilišta u Zagrebu, Svetošimunska 25, HR-10 000 Zagreb

Doc. dr. sc. Maja Moro, Zavod za procesne tehnike, Šumarski fakultet Sveučilišta u Zagrebu, Svetošimunska 25, HR-10 000 Zagreb, e-pošta: mmoro@sumfak.hr

* Corresponding author
} 

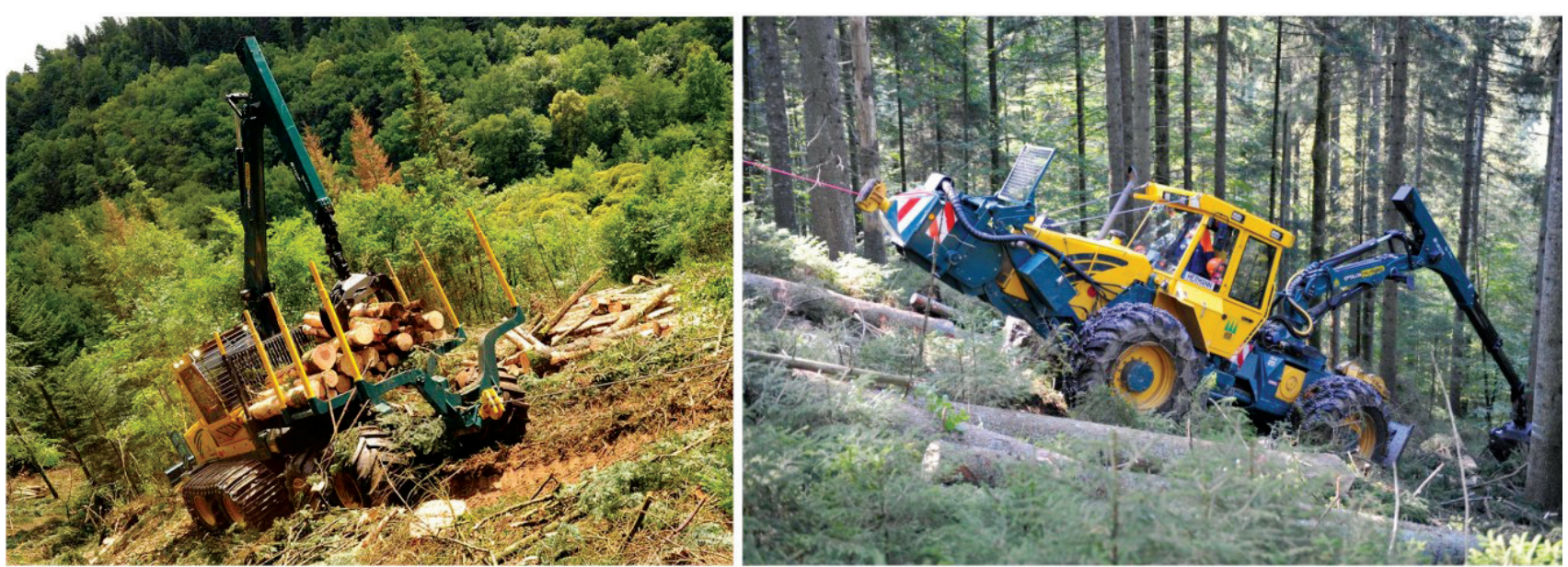

Slika 1. Šumska vozila s dodatnim vitlom

Fig. 1 Cable-assist forestry vehicles

vozila (slika 1), čime je harvesterima, forvarderima i skiderima omogućen siguran te djelotvoran rad na strmijim terenima (Visser i Stampfer 2015).

S obzirom da su šumska vozila pod utjecajem ograničenja prometnosti terena, od odlučujuće je važnosti poznavati faktore koji utječu na njihovu kretnost (Heinimann 1999). Isti autor, navodi da je temelj za znanstvena istraživanja sustava vozilo - teren, postavio Bekker 1956. godine u knjizi "Theory of Land Locomotion «, koji su tijekom vremena nadopunjavali mnogi drugi autori i istraživači (npr. Wong 1989, Mastinu i Ploechl 2014). Sam tijek razvoja šumskih vozila s obzirom na njihovu namjenu i s ciljem dosizanja njihove što veće kretnosti zasnovan je na cijelom nizu pokušaja i pogrešaka (Drushka i Konttinen 1997), pri čemu je došlo do diferencijacije četiri osnovna kretna sustava šumskih vozila: 1) kotačni, 2) gusjenični, 3) hodni te 4) hibridni (Heinimann 1999). Na primjeru harvestera, osnovne kretne sustave šumskih vozila, odlučujuće za njihov način upravljanja, ali i prohodnost/kretnost po terenskim nepravilnostima šumskoga bespuća prikazuje slika 2 .

Pri ocjenjivanju pogodnosti primjene djelomično i/ili potpuno mehaniziranih sustava pridobivanja drva do izražaja dolaze sastavnice, pokazatelji, ali i kriteriji kretnosti šumskih vozila, između kojih postoji velika povezanost i međudjelovanje (Đuka 2014, Poršinsky i Horvat 2005, Poršinsky i dr. 2012, Šušnjar 2005, Šušnjar i dr. 2010). Saževši spoznaje iz dosadašnjih objava, može se zaključiti da su sastavnice (podrazine) kretnosti šumskih vozila njihova: 1) Prohodnost, 2) Vučne značajke (ovisnost faktora vuče vozila ili vučne sile o klizanju kotača i nosivosti podloge, granični kut nagiba terena na temelju vučne značajke vozila) te 3 ) Okolišna pogodnost.

Prohodnost šumskog vozila (eng. vehicle maneuverability) određena je njegovom mogućnošću svladavanja terenskih nepravilnosti šumskoga bespuća, pri čemu dolazi do inte- rakcije dva geometrijska sustava - geometrije vozila i geometrije površine terena (Bekker 1969). Isti autor smatra da se prohodnost vozila očituje kroz: 1) mogućnost kretanja po nepravilnostima terena, 2) mogućnost upravljanja (kontrole) vozilom, ali i 3) udobnost vožnje. Navedenim, prohodnost šumskih vozila ovisi o dimenzijskim značajkama koje su određene tijekom njihove konstrukcije: 1) gabaritnim mjerama, 2) kretnim sustavom i načinom upravljanja, 3) masom vozila, odnosno položajem točke težišta. Postoje i mnogi pokazatelji koji određuju prohodnost šumskih vozila, a samim time i područje njihove operativne primjene: 1) kutovi uzdužne i bočne stabilnosti vozila (Alexandrovich 2013, Gibson i Biller 1974), 2) granični teret s obzirom na uzdužnu stabilnost vozila (Horvat 1990), 3) raspodjela opterećenja po osovinama s obzirom na nagib terena, smjer kretanja vozila i količinu privlačenoga drva (Đuka 2014, Đuka i dr. 2016), 4) vanjski i unutarnji polumjer skretanja vozila (Bekker 1969, Sever 1980) te 4) kutovi i polumjeri prohodnosti vozila (Janosi i Green 1968, Sever i Horvat 1985).

U hrvatskome šumarstvu prevladavaju djelomično mehanizirani sustavi pridobivanja drva, pri čemu se sječa i izradba drva obavlja ručno-strojnim radom primjenom motornih pila lančanica, a privlačenje drva šumskim vozilima (Tomašić 2012, Vusić 2013). Navedeno potvrđuje Đuka (2014), analizirajući podatke o udjelima privučenoga drva sredstvima trgovačkog društva »Hrvatske šume« d.o.o Zagreb za razdoblja 2002. - 2006. (Beuk i dr. 2007) i 2007. - 2011. (Tomašić 2012), gdje se uočava stalnost i prevladavanje udjela privučenoga drva skiderima ( $60 \%$ obujma), ali i rast udjela izvezenoga drva forvarderima $(19,1 \% \rightarrow 25$ $\%)$ na uštrb udjela privučenoga drva nadograđenim poljoprivrednim traktorima i traktorskim ekipažama $(21,9 \% \rightarrow$ $14,5 \%$ obujma izrađenoga drva). Na značajnost privlačenja drva skiderom $s$ vitlom primjenom (polu)deblovne metode izradbe drva, osim udjela od $60 \%$ obujma privučenoga 

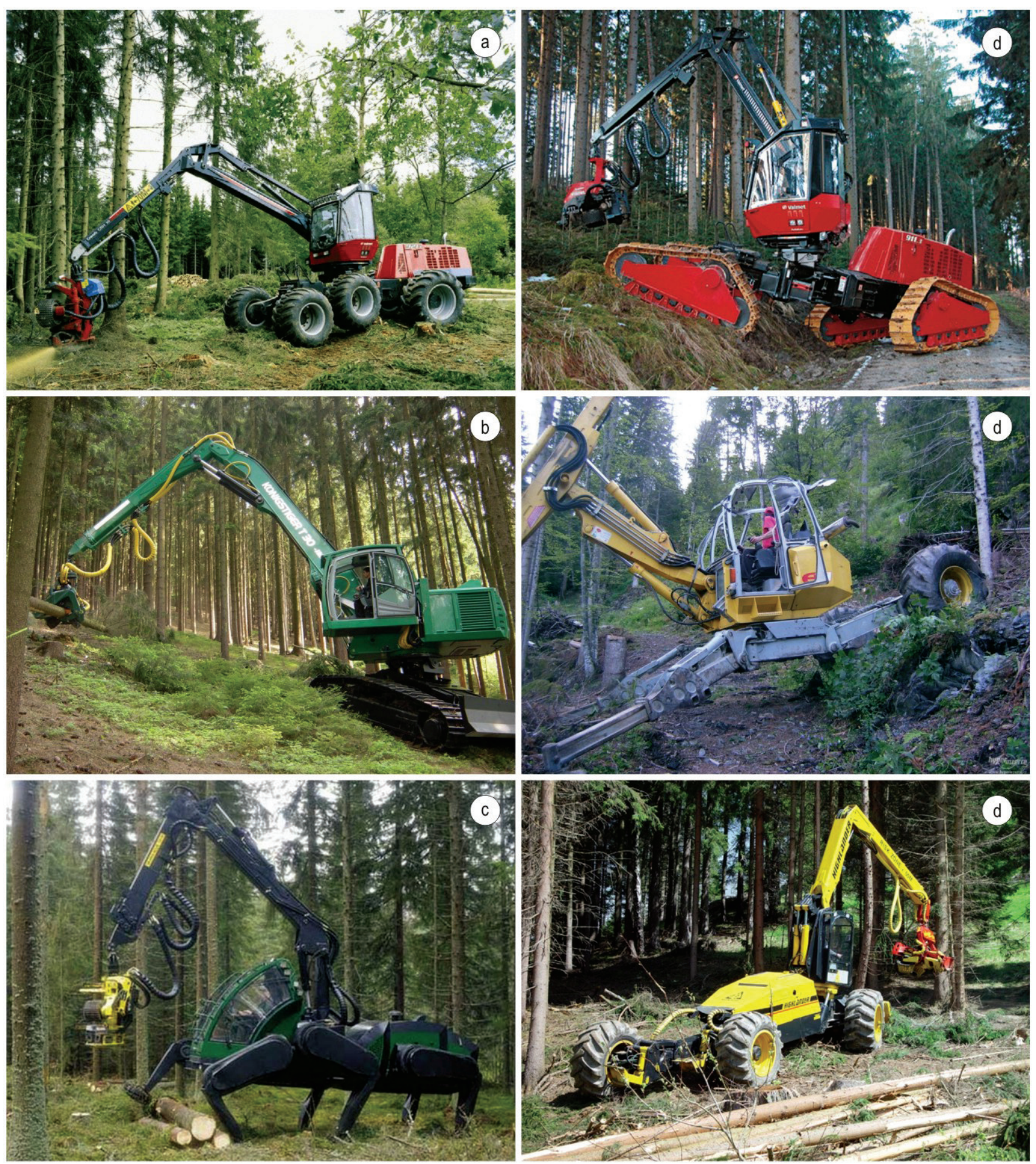

Slika 2. Kretni sustavi harvestera: a) kotačni, b) gusjenični, c) hodni, d) hibridni

Fig. 2 Harvester locomotion systems: a) wheeled, b) tracked, c) legged, d) hybrid

drva, svakako utječe i činjenica da u Republici Hrvatskoj područje brežuljkastih, brdskih i gorskih šuma (tereni s izraženim nagibom > $10 \%$ ) zauzimaju $60 \%$ površine šuma i šumskog zemljišta (Poršinsky i dr. 2012).

S obzirom na specijaliziranost namjene, norma ISO 6814 (2009) određuje skider s vitlom kao šumsko, zglobno upravljano, samohodno vozilo za privlačenje stabala ili dijelova stabala. U odnosu na druga vozila za privlačenje drva, posebnost privlačenja drva skiderom s vitlom (Đuka 2014, MacDonald 1999, Poršinsky i dr. 2012) ogleda se kroz:

$\Rightarrow$ prihvat drva vučnim užem vitla (dosega $<70 \mathrm{~m}$ ), čime je osigurano kretanje skidera isključivo po mreži sekundarnih šumskih prometnica uz sakupljanje drva sa za skider nekretnih površina terena, čime vozilo ne treba 

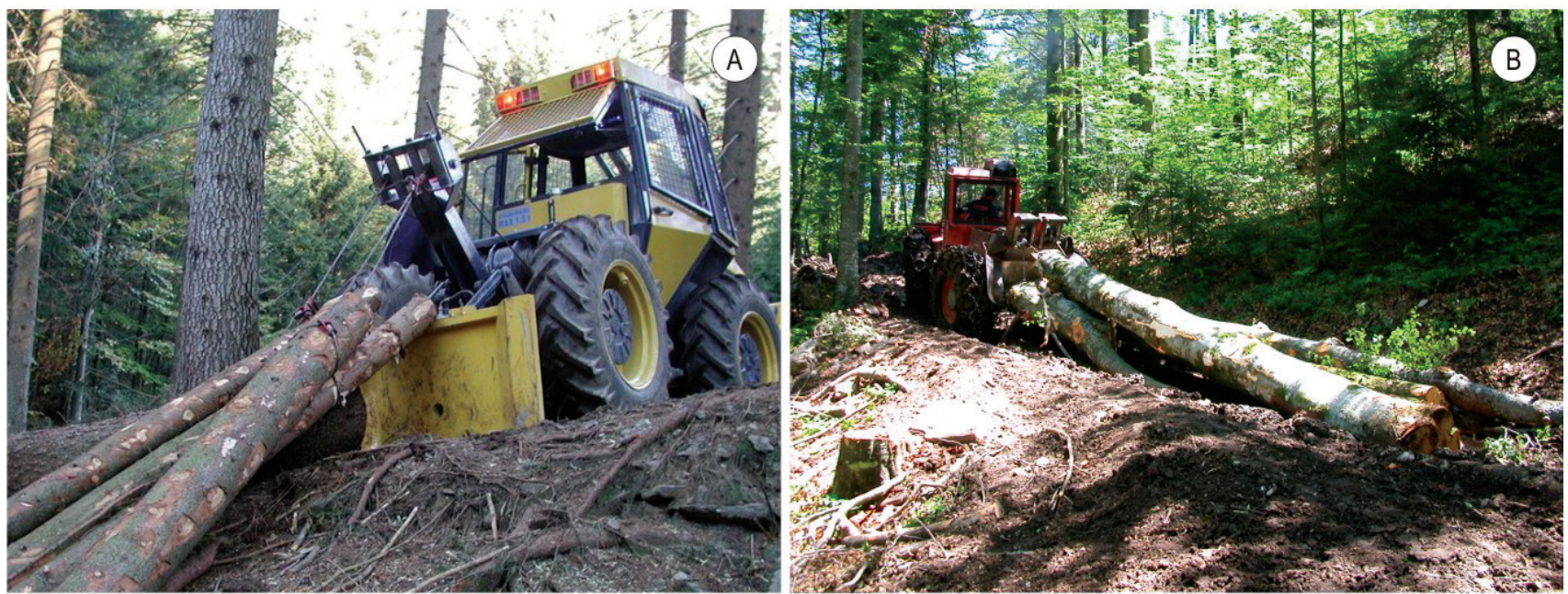

Slika 3. Sakupljanje i privlačenje drva skiderom

Fig. 3 (Pre)extraction of wood by cable skidder

prići u neposrednu blizinu posječenoga stabla ili djelomično, odnosno potpuno izrađenoga drva (slika $3 \mathrm{~A}$ ),

$\Rightarrow$ privlačenje drva se odvija $s$ jednim krajem vučenoga drva (stabla, debla, sortimenta) odignutim od tla koje je preko vučnog uža vitla ovješeno te oslonjeno na stražnju dasku skidera, dok se drugi kraj drva vuče po tlu (slika 3B), iz čega proizlazi osnovna namjena skidera - ostvarivanje vučne sile na obodu kotača,

$\Rightarrow$ uhrpavanje drva (bez mogućnosti slaganja složaja) na pomoćnome stovarištu prednjom (odrivnom) pomičnom daskom, kojom se mogu uklanjati prepreke te vršiti manje popravke na sekundarnim šumskim prometnicama,

$\Rightarrow$ dodatno opremanje skidera: 1) drugim vitlom s užem za sidrenje vozila (rad na strmim sekundarno neotvorenim terenima), 2) dizalicom (mogućnost slaganja složaja drva na pomoćnome stovarištu), 3) vučom poluprikolice (izvoženje jednometarskoga ogrijevnoga drva), proširuje se njegova namjena, odnosno područje rada.

Osim zglobnoga upravljanja, kojim se ostvaruje manji krug okretanja vozila, osnovna je značajka skidera pogon na sva četiri kotača istih dimenzija te opterećenje prednje osovine neopterećenoga vozila sa približno $2 / 3$ ukupne mase, što mu omogućuje bolju kretnost i osigurava uzdužnu stabilnosti pri privlačenju drva na nagnutim terenima (Sever 1980). Podvozje se skidera sastoji od dvaju odvojenih okvira s kotačima vozila, prednjega (motor, mjenjač, razvodnik pogona, kabina i prednja daska) i stražnjega (vitlo s horizontalnim i vertikalnim valjcima te zaštitno-prihvatna daska) koji su spojeni zglobno, s mogućnošću gibanja najčešće samo u vodoravnoj ravnini (Sever i Horvat 1985). Kabina se skidera izvodi sa zaštitnim konstrukcijama, sa svrhom
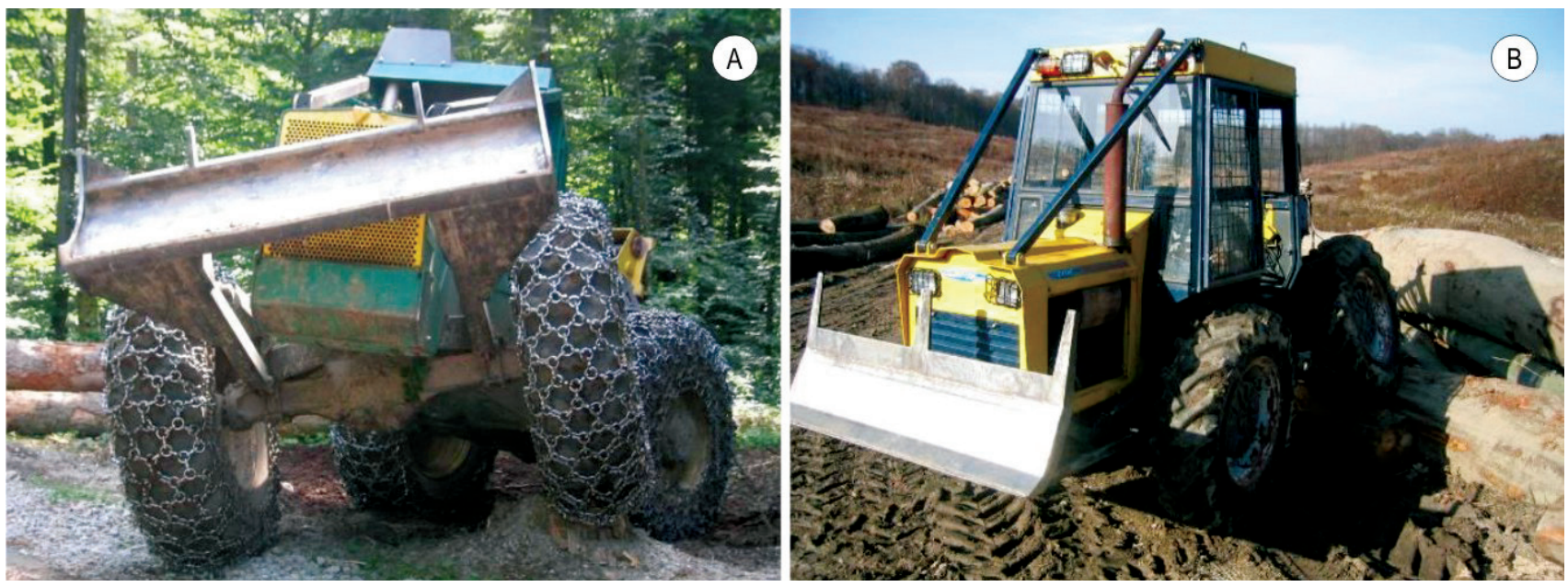

Slika 4. Poprečno prilagođavanje skidera terenu/preprekama

Fig. 4 Skidder transversal alignment to terrain/obstacle 
sigurnosti vozača pri prevrtanju vozila (ROPS) te udaru (OPS) ili padu (FOPS) predmeta (Šušnjar 2005). Poprečno prilagođavanje skidera terenu pri prelasku površinskih prepreka, najčešće je omogućeno njihanjem prednje osovine - oscilacijom osovine u oba smjera (slika 4A), čime se povećava kretnost (povećanje stabilnosti i poboljšanje vučnih svojstava), a smanjuje naprezanje šasije. Izuzetak od pravila predstavlja proredni skider Ecotrac 55V, kao jedini skider koji ima dvosmjerni - tzv. »forvarderski« zglob, čime je pri konstrukciji vozila izostala potreba za prednjom njihajućom osovinom (slika 4B).

Prihvat drva vučnim užem, utjecao je na neophodnost ugradnje vitla na stražnjem dijelu skidera, ali i dodatnim radnikom (kopčašem) pri sakupljanju drva. Sever i Horvat (1985) navode da se odabir vitla obavlja na osnovi njegove potrebne nazivne vučne sile, odnosno težine skidera, pri čemu nazivna vučna sila vitla u pravilu ne premašuje težinu vozila. Svi skideri opremljeni vitlom moraju imati stražnju (prihvatno-zaštitnu) dasku, jer se završetkom sakupljanja drva vitlom odiže oblovina ovješena o vučno uže od tla te oslanja na stražnju dasku (funkcija prihvata), a pri vuči drva skiderom stražnja daska štiti kotače i zadnju osovinu vozila (funkcija zaštite). Kod prorednih skidera manje težine, stražnja je daska pomična te se hidraulički spušta na tlo prilikom sakupljanja drva vitlom (slika 3A), s ciljem povećanja stabilnosti vozila pri ostvarivanju većih vučnih sila vitla od težine samoga skidera (funkcija sidrenja). Kod teških skidera izostaje potreba za spuštajućom stražnjom daskom zbog njihove velike težine (Gužvinec i dr. 2012). Daljinsko upravljanje vitlom, umanjuje potrebu za dodatnim radnikom kopčašem, a ugrađuje se samo kod skidera opremljenih spuštajućom (sidrenom) stražnjom daskom iz sigurnosnih razloga.

Norma ISO 13861 (2000) definira osnovne dimenzijske značajke skidera koje su prikazane na slici 5, temeljem kojih Horvat i dr. (2007) izrađuju morfološku analizu skidera s ciljem potpore: 1) odabiru novih strojeva šumarskim stručnjacima, 2) određivanju najpovoljnije uporabe skidera u različitim uvjetima rada, te 3 ) određivanju parametara pri konstrukciji novih skidera.

Cilj je ovoga rada, na primjeru skidera s vitlom, objasniti značenje kutova (prednjeg, središnjeg i stražnjeg) i radijusa (uzdužnog i poprečnog) prohodnosti šumskih vozila, kao pokazatelja njihove prohodnosti pri kretanju po nepravilnostima šumskoga bespuća. Navedeni pokazatelji, poznati su u literaturi neovisno o namjeni i primjeni vozila, a Sever i Horvat (1985) ih navode kao bitne pokazatelje prohodnosti skidera pri privlačenju drva.

Kutove i polumjere prohodnosti skidera, norma ISO 13861 (2000) ne poznaje, a u literaturi postoje samo približno točni izrazi za njihovo izračunavanje uslijed različitosti konstrukcije i primjene vozila uopće. Izvođenje izraza za izra- čun ovih pokazatelja prohodnosti skidera, uz uvažavanje posebnosti njihove konstrukcije te ustaljenost odnosa između dimenzijskih značajki neovisno o njihovim proizvođačima, predstavlja dodatni istraživački izazov.

\section{KUTOVI PROHODNOSTI SKIDERA APPROACH, RAMP (BREAK-OVER) AND DEPARTURE ANGLES OF SKIDDER}

Na kretnost, odnosno prohodnost skidera pri privlačenju drva bitna su tri kuta njegove prohodnosti: prednji, središnji i stražnji (slika 6). Ovi kutovi prohodnosti vozila, definirani su u literaturi neovisno o namjeni samoga vozila, odnosno kretanju vozila po prometnicama (ISO 612, 1978) ili bespuću terena (Janosi i Green 1968, Bekker 1969, Mastinu i Ploechl 2014).

Prednji i stražnji kut prohodnosti skidera su kutovi (gledani iz bokocrta vozila) između podloge po kojoj se vozilo kreće i tangenti na obod gume kotača iz najniže točke prednjega, odnosno najniže točke stražnjega prepusta skidera (slika 6A).

Norma ISO 612 (1978) određuje prepust vozila kao horizontalnu udaljenost između vertikalnih ravnina koje prolaze kroz simetralu prednje/stražnje osovine i ravnina koje diraju krajnje (»najisturenije«) prednje/stražnje točke vozila. Krajnju prednju točku skidera, predstavlja doljnji rub prednje (odrivne) daske pri najvećemu luku ( $L_{4}$ na slici 5), a krajnju stražnju točku skidera »najistureniji« dio prihvatno-zaštitne daske (slika 5). S obzirom, da odignuta prednja daska skidera ne ograničava njegovu prohodnost (Sever i Horvat 1985), prednji je prepust skidera određen krajnjom točkom njegova prednjeg okvira (slike 5i 6A). Gabaritne mjere prednjeg/stražnjeg prepusta skidera su lako mjerljive dimenzijske značajke skidera (ili podaci dostupni iz kataloških materijala nekih proizvođača), a norma ISO 13861 (2000) izrijekom ih ne navodi, već posredno izračunom iz normom određenih dimenzija vozila (slika 5).

Pretpostavke korištene za izračun prednjega i stražnjega kuta prohodnosti su posebnosti konstrukcije skidera, koje se ogledaju kroz ustaljenost odnosa između dimenzijskih značajki neovisno o proizvođačima skidera: 1) visina najniže točke prednjeg prepusta veća je od polumjera kotača $(a>r), 2)$ duljina prednjega prepusta veća je od polumjera kotača $(c>r), 3)$ visina najniže točke stražnjeg prepusta veća je od klirensa skidera $\left(h_{2}\right)$ i klirensa zgloba $\left(h_{1}\right)$, a manja od polumjera kotača $\left(h_{2}<h_{1}<b<r\right)$ te 4$)$ duljina stražnjega prepusta veća je od polumjera kotača $(d>r)$.

Geometrijski gledano, prednji i stražnji kut prohodnosti skidera ovise o njegovim dimenzijskim značajkama (slike 6A): 1) duljinom i visinom najniže točke prednjega, odnosno stražnjega prepusta te 2) dimenzijama (ponajprije polumjer) guma kotača kojima je skider opremljen. Zbog pro- 

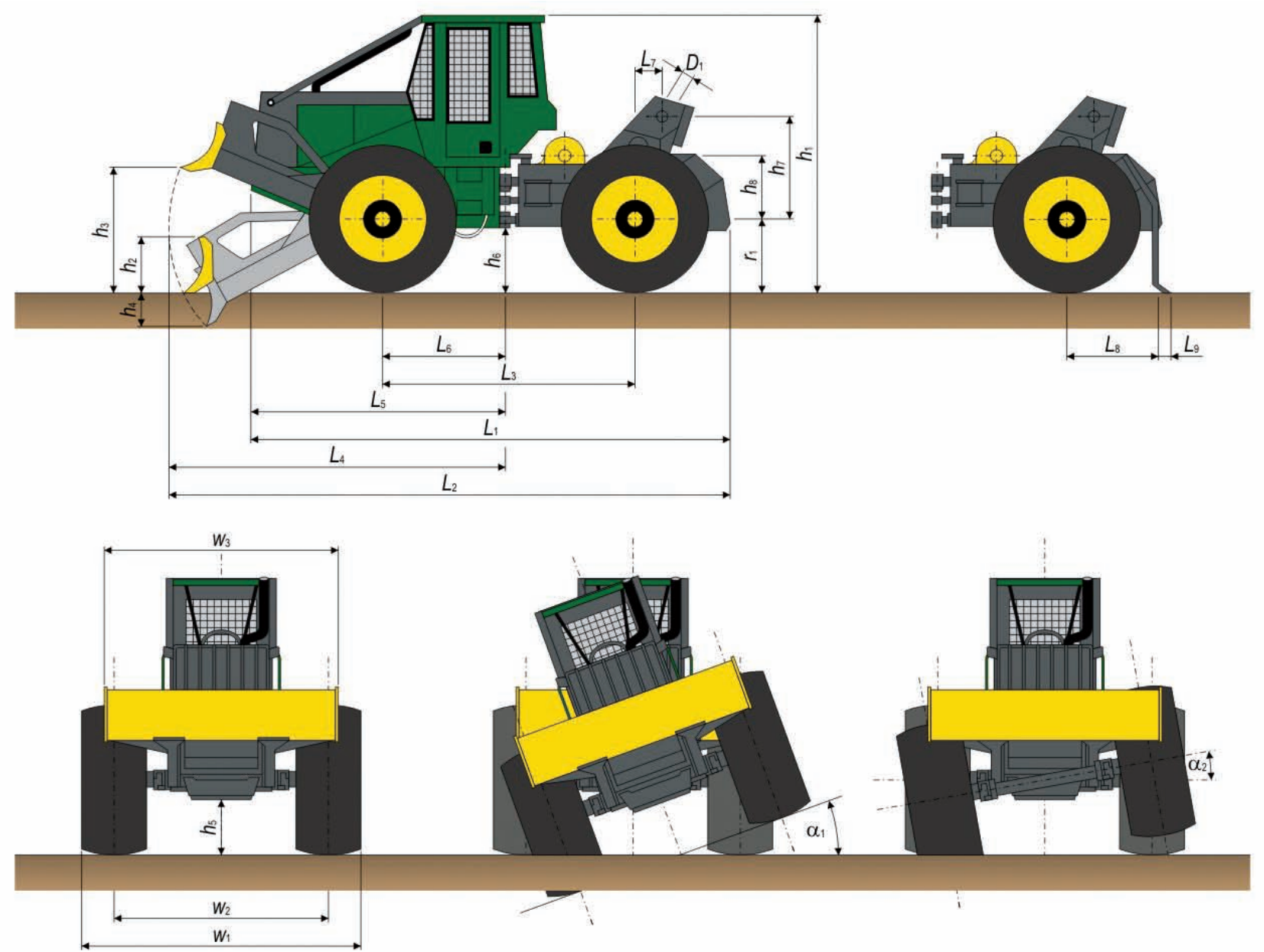

Oznake-Labels:

$D_{1}$ - Promjer horizontalnog valjka - Main fairlead roller diameter

$D_{2}$ - Vanjski promjer skretanja - Clearance circle

$L_{1}-$ Ukupna duljina okvira - Total frame length

$L_{2}$ - Ukupna duljina skidera - Overall length

$L_{3}$ - Međuosovinski razmak - Wheelbase

$L_{4}$ - Udaljenost zgloba do najvećeg luka prednje daske - Articulation joint to maximum blade arc

$L_{s}-$ Udaljenost zgloba do prednjeg dijela skidera - Articulation joint to front of machine

$L_{6}$ - Udaljenost zgloba do prednje osovine - Articulation joint to front axle

$L_{7}-$ Udaljenost stražnje osovine od horizontalnog valjka - Rear axle to main fairlead roller

$L_{8}$ - Udaljenost stražnje osovine od spuštene stražnje daske - Rear axle to butt plate

$L_{9}$ - Duljina prihvata tereta - Length of load support

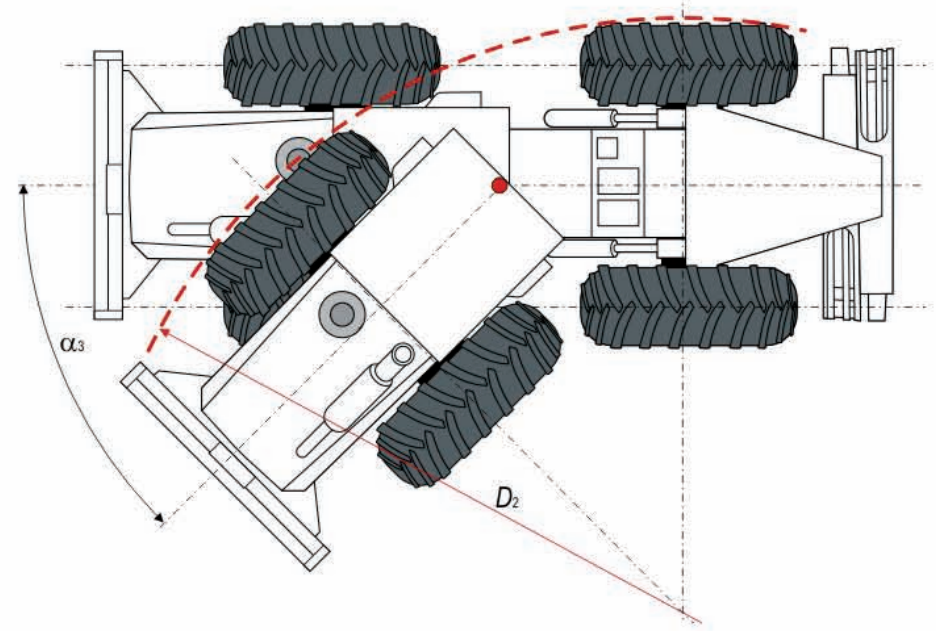

$h_{1}$ - Ukupna visina skidera - Overall height

$h_{2}$ - Visina prednje daske - Blade height

$h_{3}$ - Najveća visina podizanja donjeg ruba prednje daske Maximum blade lift of lower edge

$h_{4}$ - Najniži položaj prednje daske - Lowest blade position

$h_{5}$ - Klirens skidera - Ground clearance

$h_{6}$ - Klirens zgloba - Ground clearance at articulation joint

$h_{7}$ - Visina horizontalnog valjka - Main fairlead roller height

$h_{8}-$ Visina vitla - Winch height

$r_{1}$ - Polumjer opterećene gume - Loaded tire radius

$w_{1}$ - Ukupna širina skidera - Overall width

$W_{2}-$ Razmak kotača - Tread

$w_{3}$ - Širina prednje daske - Blade width

$\alpha_{1}-$ Kut oscilacije okvira - Frame oscillation

$\alpha_{2}$ - Kut oscilacije osovine - Axle oscillation

$\alpha_{3}-$ Kut loma zgloba - Angle of articulation

Izvor - Source: ISO 13861 (2000)

Slika 5. Dimenzijske značajke kotačnoga skidera s vitlom

Fig. 5 Dimensions of articulated rubber-tired cable skidder 


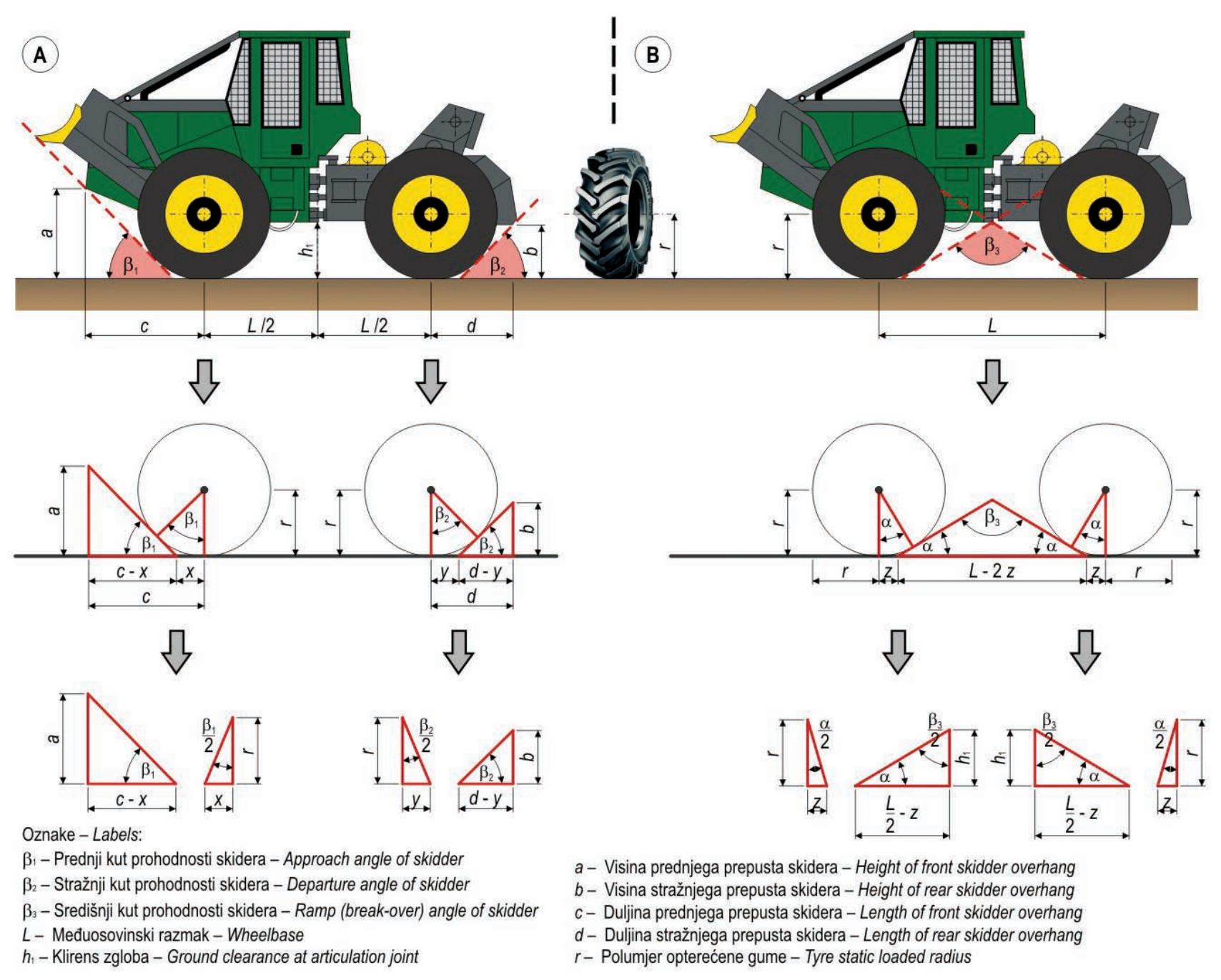

Slika 6. Prednji, središnji i stražnji kut prohodnosti skidera

Fig. 6 Approach, ramp (break-over) and departure skidder angles

giba gume opterećenoga kotača, pri izračunu kutova prohodnosti skidera autori preporučaju korištenje polumjera opterećene gume kotača, što je i u skladu s normom ISO 13861 (2000).

Ulazni kut prohodnosti skidera $\left(\beta_{1}\right)$ izračunat je primjenom trigonometrije na dva pravokutna trokuta, primjenom svojstava sličnosti trokuta te činjenicom da je tangenta na kotač uvijek okomita na polumjer kotača u točki dodira. Kod prvog trokuta, tangens ulaznog kuta (izraz 1) jednak je omjeru visine najniže točke prednjeg prepusta skidera $(a)$ i smanjene duljine prednjeg prepusta uslijed presjecanja tangentom s oboda kotača $(c-x)$. U drugom trokutu tangens polovine ulaznog kuta (izraz 2) jednak je omjeru duljine $x \mathrm{i}$ polumjera kotača $(r)$. U izrazima od 3 do 7 , primjenom trigonometrijskih identiteta, prikazan je izvod za ulazni kut prohodnosti skidera.

$$
\operatorname{tg} \beta_{1}=\frac{a}{c-x}
$$

$$
\begin{gathered}
\operatorname{tg} \frac{\beta_{1}}{2}=\frac{x}{r} \Rightarrow x=r \cdot \operatorname{tg} \frac{\beta_{1}}{2} \\
\operatorname{tg} \beta_{1}=\frac{a}{c-r \cdot \operatorname{tg} \frac{\beta_{1}}{2}} \\
\operatorname{tg} \beta_{1}=\frac{2 \cdot \operatorname{tg} \frac{\beta_{1}}{2}}{1-\operatorname{tg}^{2} \frac{\beta_{1}}{2}} \\
\frac{2 \cdot \operatorname{tg} \frac{\beta_{1}}{2}}{1-\operatorname{tg} \frac{\beta_{1}}{2}}=\frac{a}{c-r \cdot \operatorname{tg} \frac{\beta_{1}}{2}} \\
\operatorname{tg} \frac{\beta_{1}}{2}=\frac{c-\sqrt{c^{2}-a \cdot(2 \cdot r-a)}}{2 \cdot r-a} \\
\beta_{1}=2 \cdot \operatorname{arctg} \frac{c-\sqrt{c^{2}-a \cdot(2 \cdot r-a)}}{2 \cdot r-a}
\end{gathered}
$$


Stražnji kut prohodnosti skidera $\left(\beta_{2}\right)$ također je izračunat primjenom trigonometrije na dva pravokutna trokuta. Kod prvog pravokutnog trokuta, tangens stražnjeg kuta (izraz 8) jednak je omjeru visine najniže točke stražnjeg prepusta skidera $(b)$ i smanjene duljine stražnjeg prepusta uslijed presjecanja tangentom s oboda kotača $(d-y)$. U drugom trokutu tangens polovine stražnjega kuta (izraz 9) jednak je omjeru duljine $y$ i polumjera kotača $(r)$. Na istovjetan način kao i kod ulaznog kuta, primjenom trigonometrijskih identiteta izračunat je i stražnji kut prohodnosti skidera (izraz 10).

$$
\begin{gathered}
\operatorname{tg} \beta_{2}=\frac{b}{d-y} \\
\operatorname{tg} \frac{\beta_{2}}{2}=\frac{y}{r} \Rightarrow y=r \cdot \operatorname{tg} \frac{\beta_{2}}{2} \\
\beta_{2}=2 \cdot \operatorname{arctg} \frac{d-\sqrt{d^{2}-b \cdot(2 \cdot r-b)}}{2 \cdot r-b}
\end{gathered}
$$

Središnji kut prohodnosti skidera je kut (gledan iz bokocrta vozila) koji zatvaraju tangente na obod gume prednjeg i stražnjeg kotača iz najniže točke podvozja međusovinskog razmaka (slika 6B). Geometrija središnjega kuta skidera određena je ustaljenošću njegovih dimenzijskih značajki: 1) dimenzije guma prednjih i stražnjih kotača su iste, 2) približno simetrično postavljen zglob u odnosu na međuosovinski razmak (što nije tipično za ostala šumska vozila), 3) klirens zgloba je najniža točka u međuosovinskom razmaku, te 4) klirens zgloba je niži od polumjera gume opterećenoga kotača $\left(h_{1}<r\right)$. Navedenim, dimenzijske značajke koje određuju središnji kut prohodnosti skidera su: 1) međuosovinski razmak, 2) klirens zgloba i 3) polumjer gume opterećenoga kotača.

Idejno, izvod središnjeg kuta prohodnosti skidera zasniva se na jednakokračnome trokutu (slika 6B), čiji su krakovi tangente na obod prednjeg/stražnjeg kotača iz najniže točke zgloba skidera, a osnovica tog trokuta je simetrično smanjeni međuosovinski razmak $(L-2 z)$ pri čemu su kutovi uz osnovicu $(\alpha)$ jednaki. Središnji kut prohodnosti skidera $\left(\beta_{3}\right)$ izražava se preko kuta $\alpha$ (izraz 11), a izračunat je primjenom trigonometrije na dva pravokutna trokuta. Kod prvog pravokutnog trokuta, tangens kuta $\alpha$ (izraz 12) jednak je omjeru klirensa zgloba $\left(h_{1}\right)$ i smanjene polovine međuosovinskoga razmaka $(L / 2-z)$. U drugom trokutu tangens polovine kuta $\alpha$ (izraz 13) jednak je omjeru duljine $z$ i polumjera kotača $(r)$. U izrazima 14 do 16, primjenom trigonometrijskih identiteta, prikazan je izvod za kut $\alpha$ i iz njega izraženi središnji kut prohodnosti skidera $\left(\beta_{3}\right)$.

$$
\begin{gathered}
\beta_{3}=180^{\circ}-2 \alpha \\
\operatorname{tg} \alpha=\frac{h_{1}}{\frac{L}{2}-z}
\end{gathered}
$$

$$
\begin{gathered}
\operatorname{tg} \frac{\alpha}{2}=\frac{z}{r} \Rightarrow z=r \cdot \operatorname{tg} \frac{\alpha}{2} \\
\operatorname{tg} \alpha=\frac{h_{1}}{\frac{L}{2}-r \cdot \operatorname{tg} \frac{\alpha}{2}} \\
\alpha=2 \cdot \operatorname{arctg} \frac{\frac{L}{2}-\sqrt{\left(\frac{L}{2}\right)^{2}-h_{1} \cdot\left(2 \cdot r-h_{1}\right)}}{2 \cdot r-h_{1}} \\
\beta_{3}=180^{\circ}-4 \cdot \operatorname{arctg} \frac{\frac{L}{2}-\sqrt{\left(\frac{L}{2}\right)^{2}-h_{1} \cdot\left(2 \cdot r-h_{1}\right)}}{2 \cdot r-h_{1}}
\end{gathered}
$$

Važnost poznavanja kutova prohodnosti šumskih vozila, na primjeru zglobnog traktora s vitlom, prikazana je na slici 7. Prednji i stražnji kut prohodnosti skidera ograničavaju kretanje pri privlačenju drva po nepravilnostima šumskoga terena tijekom izvršavanja aktivnosti nekih radih sastavnica (zauzimanje položaja za formiranje tereta, okretanja vozila, uhrpavanje drva,...) traktorskoga turnusa (slika 7A), odnosno tijekom kretanja (ne)opterećenoga skidera posebno u točkama spojeva primarne i sekundarne šumske infrastrukture (slika 7C). U slučajevima potrebe svladavanja konkavnih nepravilnosti terena (slika 7B), koje se očituju kroz veće depresije terena, odnosno široke i plitke vrtače te obale i korita povremenih vodotoka, do izražaja dolazi središnji kut prohodnosti skidera koji ograničava njegovu kretnost.

Iako pravila dobre struke ograničavaju kretanje šumskim vozilima po mreži obilježenih traktorskih vlaka (na prometnim terenima) ili izgrađenih traktorskih putova (na neprometnim terenima), vrlo je često prisutna pojava kretanja vozila po šumskome bespuću uslijed nedovoljne gustoće i/ili neodgovarajućega prostornoga rasporeda sekundarnih prometnica (Borz i dr. 2015, Krč i dr. 2015, Košir 2008B, Pentek i dr. 2010), čime se omogućava prihvat drva vozilima (vučnim užem vitla, hidraučinom dizalicom sa hvatalom ili sječnom glavom). Posljedice kretanja šumskih vozila po šumskom bespuću su višestruke i ogledaju se kroz: 1) gaženje i sabijanje tla (Allman i dr. 2015, Borchert i dr. 2015, Labelle i dr. 2015, Kleibl i dr. 2014, Naghdi i Solgi 2014, Marenče 2014, Pandur i dr. 2014, Poršinsky i Stankić 2006, Poršinsky i dr. 2011, Solgi i dr. 2015), 2) oštećivanje nedoznačenih stabala i pomlatka (Danilović i dr. 2015, Košir 2008A, Petreš 2006, Poršinsky i dr. 2004, Poršinsky i Ožura 2006, Sabo 2003, Siren i dr. 2015, Spinelli i dr. 2014) te 3) oštećivanje šumskih vozila (Akinbamowo and Akinnuli 2015).

Upravo je mogućnost oštećivanja vozila pri kretanju po bespuću glavni razlog važnosti poznavanja kutova prohodnosti vozila, za koje Bekker (1969) navodi da su to oni kutovi nepravilnosti terena koje vozilo može svladati bez da udari u prepreku terena te tako ošteti vozilo. Isti autor, određuje 

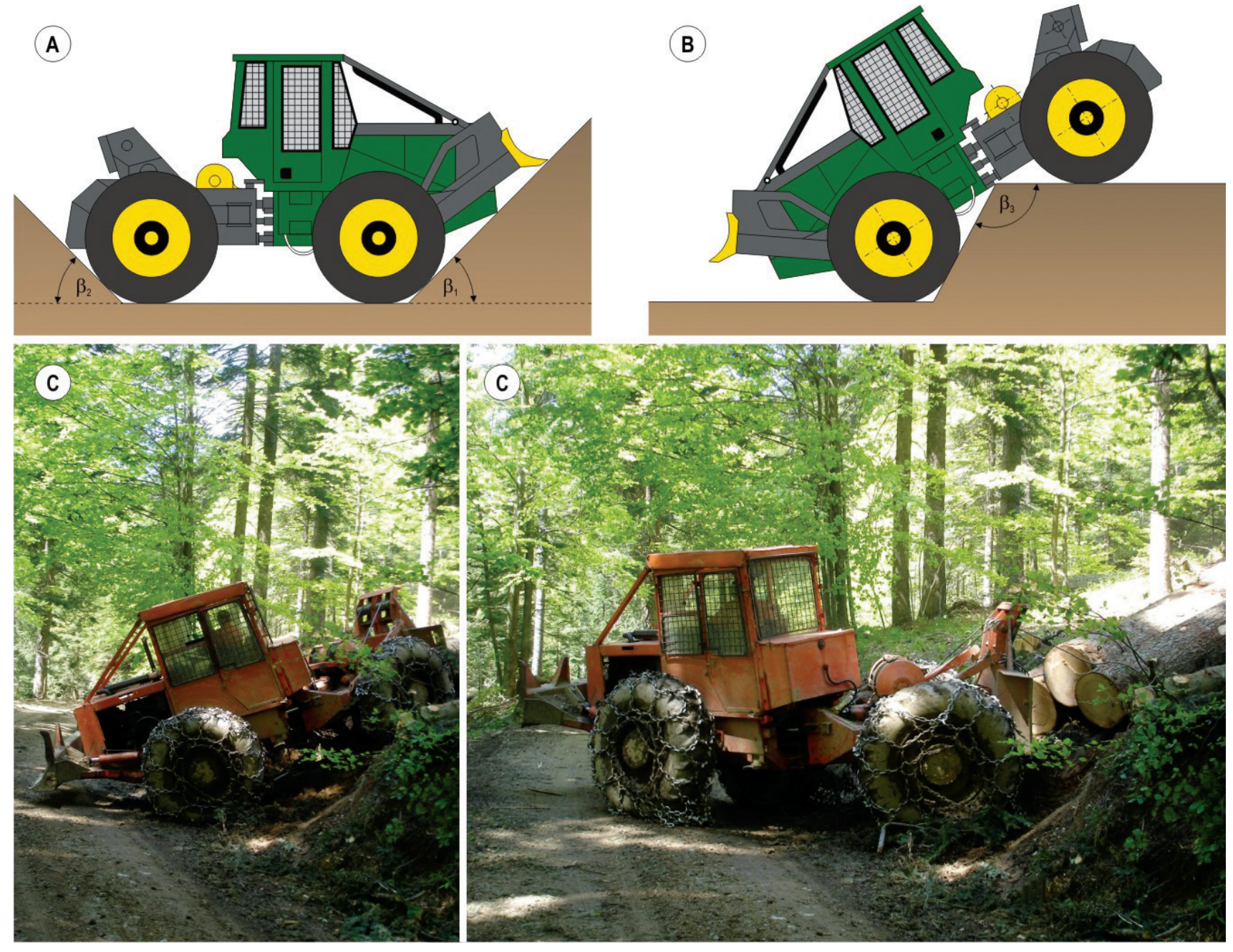

Slika 7. Utjecaj kutova prohodnosti na kretnost skidera

Fig. 7 Impact of approach, ramp (break-over) and departure angles on skidder mobility

dva slučaja neuspješne prohodnosti vozila: 1) udaranje prednjim/stražnjim krajem vozila o prepreku (NIP - Nosein-failure) i 2) udaranje središnjim dijelom vozila o prepreku (HUP - Hang-up-failure). Za vozila koja imaju prednji i stražnji kut prohodnosti u rasponu od $30^{\circ}$ do $40^{\circ}$, Bekker smatra da imaju dobru prohodnost po bespuću, dok Sever i Horvat (1985) za skider s vitlom navode veće zahtjeve $\left(35-50^{\circ}\right)$.

\section{POLUMJERI PROHODNOSTI SKIDERA CLEAREANCE RADII OF SKIDDER}

Za prohodnost zglobno upravljanih šumskih vozila pri kretanju po nepravilnostima terena za koji su znakovita mikroreljefna ispupčenja (kamenitost, stjenovitost, panjevi posječenih stabala,...) bitne su dvije dimenzijske značajke koje određuju najniže točke podvozja (klirens ili »zračnost«) vozila. Najniža točka podvozja (klirens) šumskih vozila vezana je najčešće uz prednji diferencijal i nalazi se između kotača prednje osovine, dok je klirens zgloba najniža točka međuosovinskog razmaka (slika 5). U odnosu na klirens skidera i klirens zgloba, Sever i Horvat (1985) ističu uzdužni te poprečni polumjer prohodnosti kao kompleksnije (dvodimenzionalne) načine iskazivanja prohodnosti šumskih vozila. Ovi polumjeri prohodnosti vozila, poznati su u literaturi ponajprije vezanoj za kretnost vozila po bespuću terena (Bekker 1969, Mastinu i Ploechl 2014).

Uzdužni polumjer prohodnosti skidera $\left(R_{1}\right)$ je polumjer (gledan iz bokocrta vozila) kružnice koja dodiruje prednji i stražnji kotač te najnižu točku podvozja međuosovinskoga razmaka (klirens zgloba) skidera (slika 8A). Posebno valja istaknuti da je geometrija uzdužnoga polumjera prohodnosti skidera određena istom ustaljenošću dimenzijskih značajki skidera, kao i središnji kut njegove prohodnosti.

Izvod uzdužnoga polumjera prohodnosti skidera zasniva se na jednakokračnome trokutu (slika $8 \mathrm{~A}$ ) čiju osnovicu predstavlja međuosovinski razmak $(L)$, a krakovi zbroj polumjera kotača i uzdužnoga polumjera prohodnosti $\left(r+R_{1}\right)$. Spuštanjem visine iz najniže točke zgloba, jednakokračni trokut se dijeli na dva osnosimetrična pravokutna trokuta, čije su katete $L / 2$ te $R_{1}+r-h_{1}$ i hipotenuza $r+R_{1}$ (izraz 17). 
Uzdužni polumjer prohodnosti skidera (izraz 18) izražen je preko: 1) međuosovinskog razmaka $(L), 2)$ klirensa zgloba $\left(h_{1}\right)$ te opterećenoga polumjera gume kotača $(r)$.

$$
\begin{gathered}
\left(r+R_{1}\right)^{2}=\left(\frac{L}{2}\right)^{2}+\left(R_{1}+r-h_{1}\right)^{2} \\
R_{1}=\frac{L^{2}}{8 \cdot h_{1}}+\frac{h_{1}}{2}-r
\end{gathered}
$$

Poprečni polumjer prohodnosti skidera je polumjer (gledan iz nacrta vozila) kružnice koja dodiruje unutarnji rub guma prednjih kotača skidera te najnižu točku podvozja (slika 8B). Geometriju poprečnog polumjera prohodnosti skidera određuju: 1) razmak kotača, 2) širina gume (kojom je skider opremljen), te 3) klirens skidera.
Izvod poprečnog polumjera prohodnosti skidera zasniva se na jednakokračnome trokutu (slika 8B), čija je osnovica jednaka razlici razmaka kotača i širine gume $(w-b)$, a visina na osnovicu je polumjer upisane kružnice između lijevoga i desnog kotača umanjen za klirens skidera $\left(R_{2}-h_{2}\right)$.

Visina na osnovicu jednakokračnoga trokuta dijeli ga na dva osnosimetrična pravokutna trokuta, čije su katete $(w-$ b)/2 i $R_{2}-h_{2}$ te hipotenuza $R_{2}$ (izraz 19). Poprečni polumjer prohodnosti skidera (izraz 20) izražen je preko: 1) razmaka kotača, 2) širine gume, te 3) klirensa skidera.

$$
\begin{gathered}
\left(R_{2}\right)^{2}=\left(\frac{w-b}{2}\right)^{2}+\left(R_{2}-h_{2}\right)^{2} \\
R_{2}=\frac{(w-b)^{2}}{8 \cdot h_{2}}+\frac{h_{2}}{2}
\end{gathered}
$$

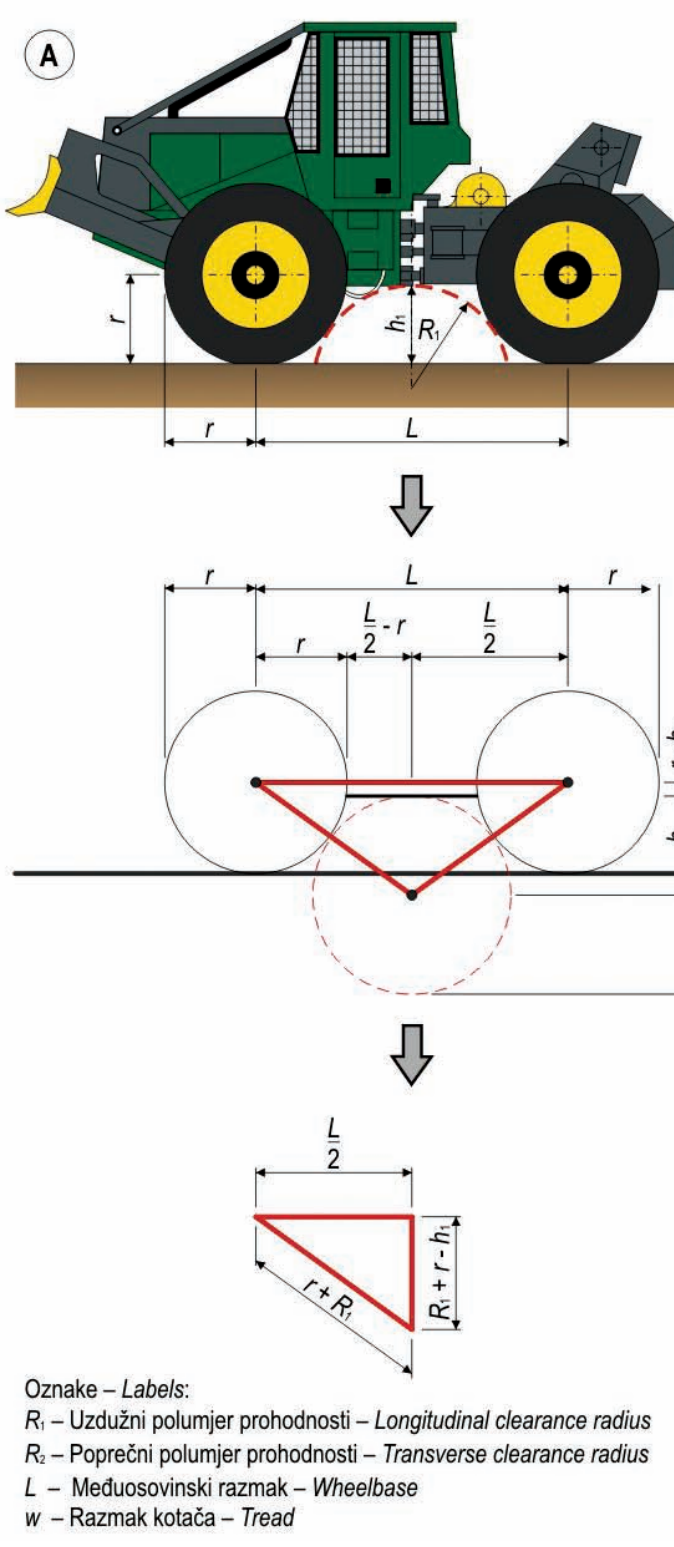

Slika 8. Uzdužni i poprečni polumjer prohodnosti skidera Fig. 8 Longitudinal and transversal clearance radii of skidder $h_{1}$ - Klirens zgloba - Ground clearance at articulation joint $h_{2}$ - Klirens skidera - Ground clearance $r$ - Polumjer opterećene gume - Tyre static loaded radius b - Širina gume - Tyre width

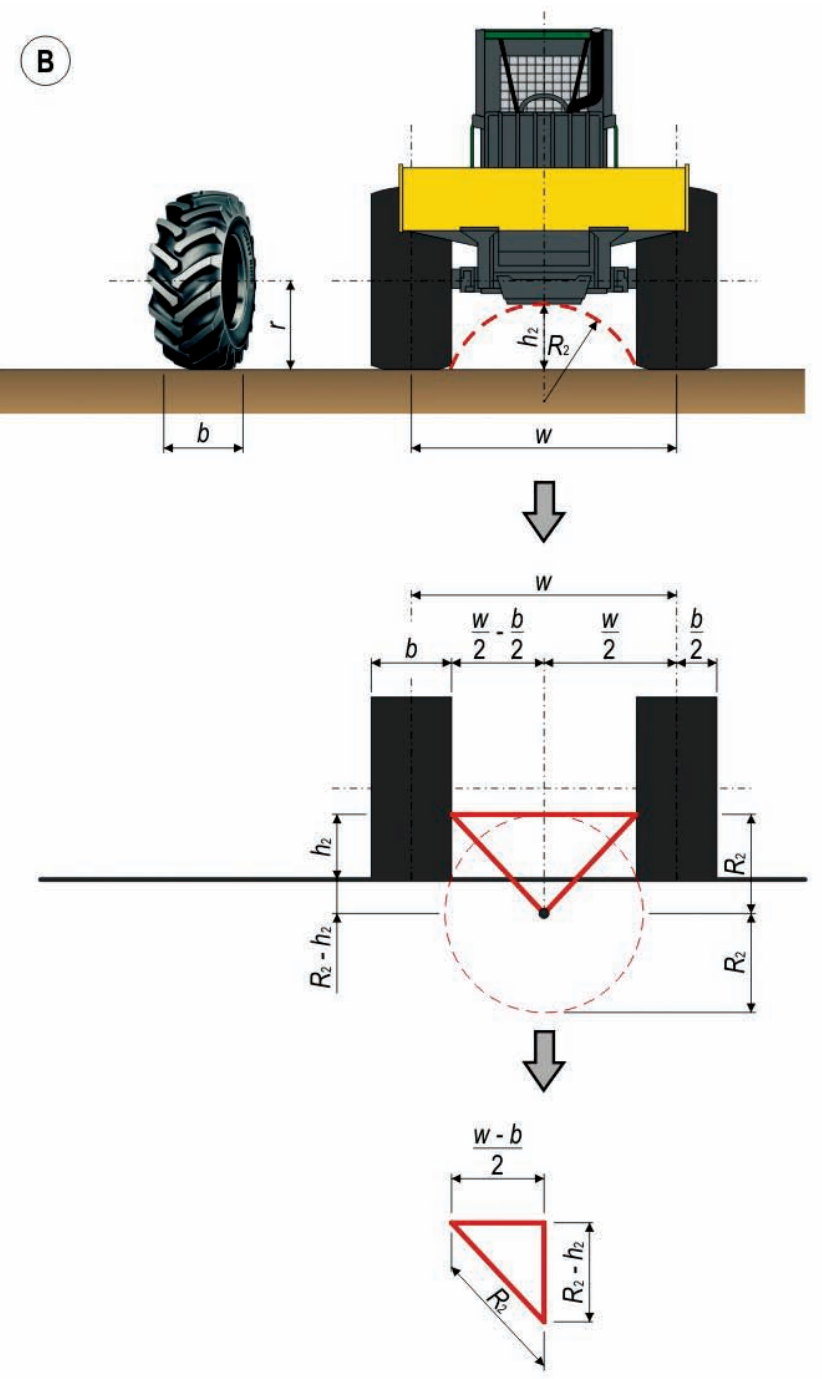


Tablica 1. Razredba površinskih prepreka (Löffler 1984, Rowan 1996)

Table 1 Ground obstacle classification (Löffler 1984, Rowan 1996)

\begin{tabular}{|c|c|c|c|c|}
\hline \multirow{2}{*}{$\begin{array}{l}\text { Razredi neravnosti } \\
\text { Roughness Class }\end{array}$} & \multicolumn{4}{|c|}{ Razredi visina površinskih prepreka - Height Class of Obtacles } \\
\hline & H $20(10-30 \mathrm{~cm})$ & $\mathrm{H} 40(30-50 \mathrm{~cm})$ & H $60(50-70 \mathrm{~cm})$ & $\mathrm{H} 80$ (> $70 \mathrm{~cm})$ \\
\hline \multirow{3}{*}{1} & Rijetke - Infrequent & \multicolumn{3}{|c|}{ Pojedinačne prepreke ostalih razreda - Other classes combined $=$ Isolated } \\
\hline & $\left(40-400\right.$ ha $\left.^{-1}, 5-16 \mathrm{~m}\right)$ & \multicolumn{3}{|c|}{$\left(4-40 \mathrm{ha}^{-1}, 16-50 \mathrm{~m}\right)$} \\
\hline & Umjereno učestale & \multicolumn{3}{|c|}{ Nisu prisutne prepreke ostalih razreda - No other classes present } \\
\hline \multirow{3}{*}{2} & Moderately frequent & Rijetke - Infrequent & \multirow{2}{*}{\multicolumn{2}{|c|}{$\begin{array}{l}\text { Pojedinačne prepreke ostalih razreda - Other classes } \\
\text { combined }=\text { Isolated }\left(4-40 \mathrm{ha}^{-1}, 16-50 \mathrm{~m}\right)\end{array}$}} \\
\hline & $\left(400-4000 \mathrm{ha}^{-1}, 1,6-5 \mathrm{~m}\right)$ & $\left(40-400 \mathrm{ha}^{-1}, 5-16 \mathrm{~m}\right)$ & & \\
\hline & \multicolumn{4}{|c|}{ Nisu prisutne prepreke ostalih razreda - No other classes present } \\
\hline \multirow[b]{2}{*}{3} & \multirow{4}{*}{$\begin{array}{l}\text { Učestale - Frequent } \\
\left(>4000 \mathrm{ha}^{-1},<1,6 \mathrm{~m}\right)\end{array}$} & \multirow{4}{*}{$\begin{array}{c}\text { Umjereno učestale } \\
\text { Moderately frequent } \\
\left(400-4000 \text { ha }^{-1}, 1,6-5 \mathrm{~m}\right)\end{array}$} & & Pojedinačne - Isolated \\
\hline & & & Rijetke - Infrequent & $\left(4-40 \mathrm{ha}^{-1}, 16-50 \mathrm{~m}\right)$ \\
\hline \multirow{2}{*}{4} & & & $\left(40-400 \mathrm{ha}^{-1}, 5-16 \mathrm{~m}\right)$ & Rijetke - Infrequent \\
\hline & & & & $\left(40-400 \mathrm{ha}^{-1}, 5-16 \mathrm{~m}\right)$ \\
\hline 5 & Sve površine s & nostima terena većim od razr & $4-$ All combinations more & ere than Class 4 \\
\hline
\end{tabular}

Značenje polumjera prohodnosti skidera pri privlačenju drva po nepravilnostima terena prikazuje slika 9. Dugačka valovita ispupčenja terena (humci, džombe,...) okomita na smjer kretanja skidera ograničavaju njegovu kretnost za vrijednost uzdužnog polumjera prohodnosti (slika 9A). Ovaj pokazatelj prohodnosti šumskih vozila treba povezati i sa polumjerima vertikalnih konveksnih krivina zaobljene nivelete pri projektiranju/gradnji traktorskih putova, čije su vrijednosti višestruko veće u odnosu na uzdužni polumjer prohodnosti skidera uslijed vuče (polu)deblovnom metodom izrađenoga drva.

Uz najnižu točku podvozja vozila, poprečni polumjer prohodnosti skidera (slika 9B), svakako treba povezati s opisnim razredbama terena za izvođenje šumskih radova (Đuka i dr. 2015, Löffler 1984, Eriksson 1975, Mellgren 1980, Rowan 1996) koje površinske prepreke raščlanjuju u pet razreda neravnosti terena (tablica 1 ) s obzirom na učestalost (gustoća po jedinici površine, odnosno međusobni razmak) prepreka određenoga visinskog razreda. Uslijed svojih dimenzijskih značajki skideri, svladavaju (razred 1) ili zaobilaze (razred 2) površinske prepreke (Krieg i dr. 2010,
McEwan i dr. 2013), dok u težim uvjetima kamenitosti/stjenovitosti terena (razredi površinskih prepreka 3 - 5) gradnja mreže traktorskih putova omogućuje kretnost skiderima, odnosno privlačenje drva.

U hrvatskome šumarstvu nema dostupnih prostornih podataka o površinskim preprekama sa stajališta kretnosti šumskih vozila, već se u osnovama/programima gospodarenja šumama, kao element staništa, kamenitost odjela/odsjeka iskazuje udjelom pokrovnosti površine (Đuka i Poršinsky 2015). Isti autori, na primjeru GJ »Kupjački vrh«, provode prostornu analizu pojavnosti pojedinih razreda površinskih prepreka sa svrhom procjene prometnosti terena za privlačenje drva.

\section{UMJESTO ZAKLJUČKA INSTEAD OF CONCLUSION}

Prvenstvena namjera ovoga rada nije "ponovno otkrivanje» već postojećih i poznatih pokazatelja prohodnosti/kretnosti šumskih vozila ili izvođenje izraza za njihovo izračunavanje na osnovi lako mjerljivih ili dostupnih (iz kataloških mate-
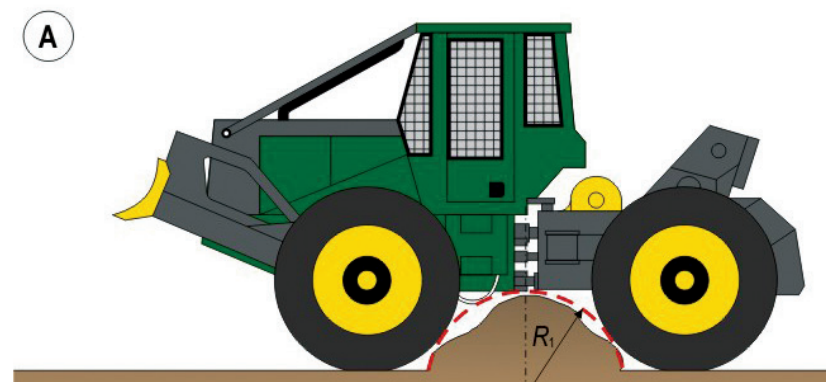
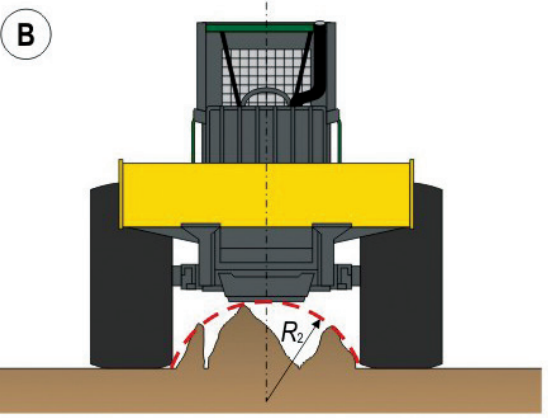

Slika 9. Utjecaj polumjera prohodnosti na kretnost skidera

Fig. 9 Impact of cleareance radii on skidder mobility 

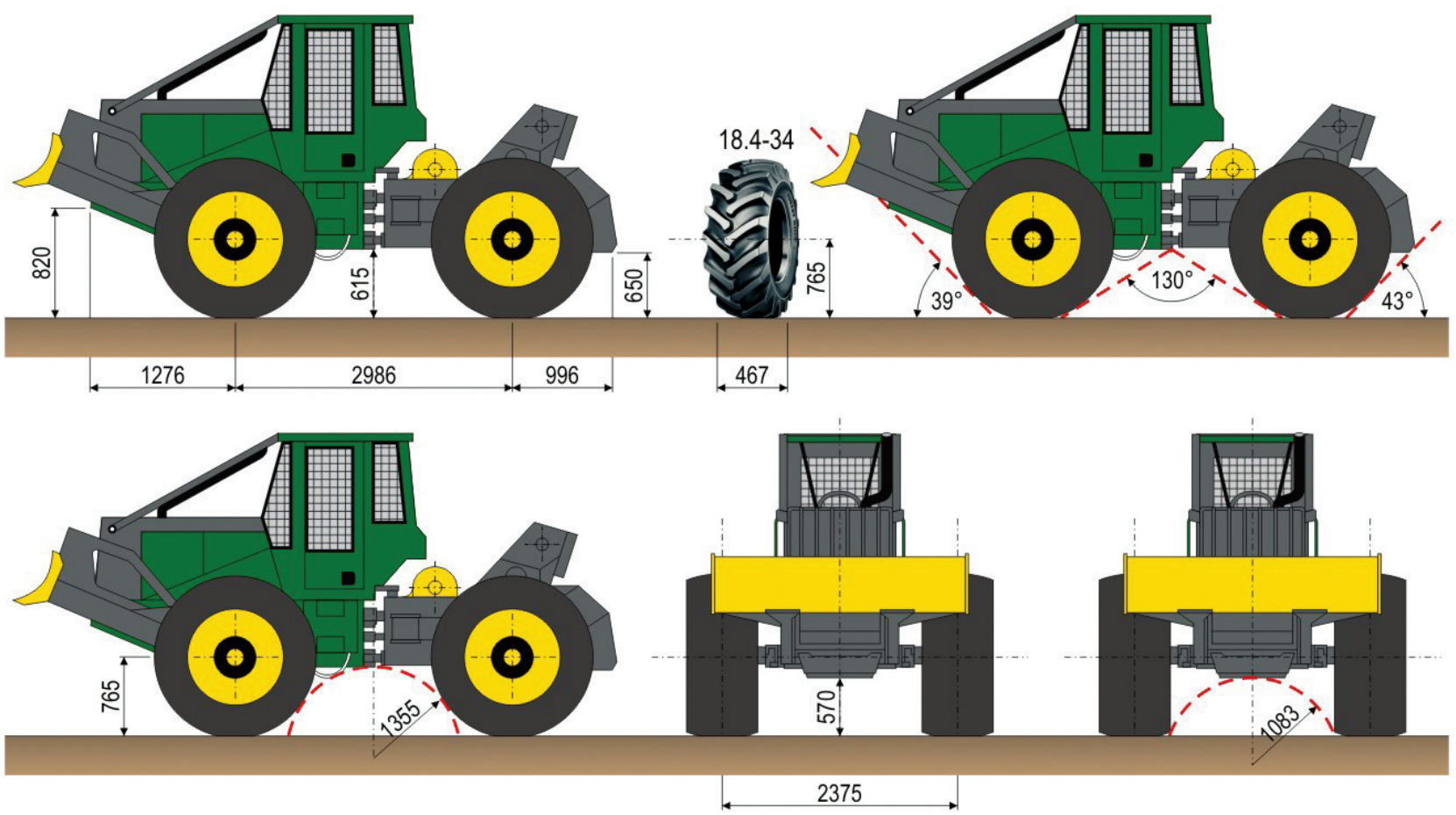

Slika 10. Kutovi i polumjeri prohodnosti skidera Timberjack $240 \mathrm{C}$ Fig. 10 Maneuverability of Timberjack 240C Skidder

rijala proizvođača strojeva, odnosno guma) dimenzijskih značajki, već pojašnjenje njihovoga značenja, sa svrhom:

$\Rightarrow$ Usporedbe među šumskim vozilima prilikom odabira novih strojeva.

$\Rightarrow$ Ocjenjivanju pogodnosti primjene šumskih vozila pri različitim uvjetima rada s ciljem otklanjanja mogućih oštećivanja strojeva u njihovome uporabnom ili amortizacijskom razdoblju. Njemački KWF (Kuratorium für Wadarbeit und Forsttechnik), određuje za skider s vitlom ukupno vrijeme uporabe 15 godina ili 17.000 (14.000 - 19.000) pogonskih sati, odnosno razdoblje amortizacije od 9 godina ili 10.200 pogonskih sati (Forbig i Büttner 2013).

$\Rightarrow$ smjernica proizvođačima šumskih vozila i atestnim institucijama za iskazivanjem dodatnih dimenzijskih značajki, odnosno pokazatelja prohodnosti (slika 10).

\section{LITERATURA REFERENCES}

- Akinbamowo, R.O., Akinnuli, B.O., 2015: The Effects of Mechanised Log Skidding on some Components of Farm Tractors in Ondo State, Nigeria. Croat. j. for. eng. 36(2): 253-258.

- Alexandrovich, Y.K., 2013: The Issue of Evaluation of Stability of Skidders. World Applied Sciences Journal 24(7): 971-979.

- Allman, M., Ferenčík, M., Jankovský, M., Stanovský, M., Messingerová, V., 2015: Damage Caused by Wheeled Skidders on Cambisols of Central Europe. Croat. j. for. eng. 36(2): 205-215.
- Bekker M.G., 1956: Theory of Land Locomotion, University of Michigan Press, 1-499.

- Bekker, M.G., 1960: Theory of land Locomotion - The Mechanics of Vehicle Mobility. The University of Michigan Press, USA, 1-497.

- Bekker, M.G., 1969: Introduction to Terrain - Vehicle Systems. The University of Michigan Press, USA, 1-846.

- Beuk, D., Tomašić, Ž., Horvat, D., 2007: Status and Development of Forest Harvesting Mechanization in Croatian State Forestry. Croat. j. for. eng. 28(1): 63-82.

- Borchert, H., Huber, C., Göttlein, A., Kremer, J., 2015: Nutrient Concentration on Skid Trails under Brush-Mats - Is a Redistribution of Nutrients Possible? Croat. j. for. eng. 36(2): 243-252.

- Borz, S.A., Ignea, G., Popa, B., Spârchez, G., Iordache, E., 2015: Estimating Time Consumption and Productivity of Roundwood Skidding in Group Shelterwood System - a Case Study in a Broadleaved Mixed Stand Located in Reduced Accessibility Conditions. Croat. j. for. eng. 36(1): 137-146.

- Danilović, M., Kosovski, M., Gačić, D., Stojnić, D., Antonić, S., 2015: Damage to Residual Trees and Regeneration During Felling and Timber Extraction in Mixed and Pure Beech Stands. Šum. list 139(5-6): 253-262.

- Drushka, K., Konttinen, H., 1997: Tracks in the Forest: The Evolution in Logging Machinery. Timberjack Group, Helsinki, $1-254$.

- Đuka, A., 2014: Razvoj modela prometnosti terena za planiranje privlačenja drva skiderom. Disertacija, Šumarski fakultet Sveučilišta u Zagrebu, 1-303.

- Đuka, A., Poršinsky, T., Vusić, D., 2015: DTM Models to Enhance Planning of Timber Harvesting. Bulletin of The Faculty of Forestry Beograd, Special Issue, 35-44. 
- Đuka, A., Poršinsky, T., 2015: Analiza kamenitosti i stjenovitosti terena za potrebe privlačenja drva. Nova meh. šumar. 36 : 43-52.

- Đuka, A., Pentek, T., Horvat, D., Poršinsky, T., 2016: Modelling of Downhill Timber Skidding: Bigger Load - Bigger Slope. Croat. j. for. eng. 37(1): 139-150.

- Eichrodt, A.W., Heinimann, H.R., 2001: Mobility of Timber Harvesting Vehicles. Proceedings »Appalachian Hardwoods: Managing Change«, Council on Forest Engineering (COFE), July 15-18, 2001, Snowshoe, USA, 1-6.

- Eichrodt, A.W., 2003: Development of a Spatial Trafficability Evaluation System. PhD Thesis, ETH Zurich, 1-165.

- Enache, A., Pentek, T., Ciobanu, V.D., Stampfer, K., 2015: Gis Based Methods for Computing the Mean Extraction Distance and its Correction Factors in Romanian Mountain Forests. Šum. list 139(1-2): 35-46.

- Eriksson, T., Nilsson, G., Skrămo, G., 1975: The Inter-Nordic Project of Forest Terrain and Machines in 1972-1975. Acta Forestalia Fennica 164: 1-44.

- Forbig, A., Büttner, I., 2013: Forstmaschinen vorauskalkulieren. Kwf Merkblatt Nr. 17/2013: 1-35.

- Gibson, H.G., Biller, C.J., 1974: Side-Slope Stability of Logging Tractors and Forwarders. Transactions of the ASAE 17(2): 245250.

- Gužvinec, H., Zorić, M., Šušnjar, M., Horvat, D., Pandur, Z., 2012: Utjecaj načina sidrenja na vrijednosti horizontalne sastavnice vučne sile i faktor prianjanja prilikom privitlavanja drva skiderom i adaptiranim poljoprivrednim traktorom. Nova meh. Šumar. 33: 23-33.

- Heinimann, H.R., 1995: Mechanisierte Holzernte in Hanglagen. Wald und Holz (76)11: 32-36.

- Heinimann, H.R., 1999: Ground-based harvesting technologies for steep slopes. In: Proceedings of the International Mountain Logging and 10th Pacific Northwest Skyline Symposium, Sessions and Chung (editors), March 28 - April 1, Corvallis, Oregon, USA, 1-19.

- Horvat, D., 1990: Predviđanje vučnih karakteristika šumskog zglobnog traktora - skidera. Meh. šumar. 15(7-8): 113-118.

- Horvat, D., Zečić, Ž., Šušnjar, M., 2007: Morphological Characteristics and Productivity of Skidder Ecotrac 120V. Croat. j. for. eng. 28(1): 11-25.

- ISO 612, 1978: Road vehicles - Dimensions of motor vehicles and towed vehicles - Terms and definitions, 1-15.

- ISO 6814, 2009: Machinery for forestry - Mobile and self-propelled machinery - Terms, definitions and classification, 1-7.

- ISO 13861, 2000: Machinery for forestry - Wheeled skidders Terms, definitions and commercial specifications, 1-9.

- Janosi, Z., Green, A.J., 1968: Glossary of terrain-vehicle terms. Journal of Terramechanics 5(2): 53-69.

- Kleibl, M., Klvač, R., Lombardini, C., Porhaly, J., Spinelli, R., 2014: Soil Compaction and Recovery after Mechanized Final Felling of Italian Coastal Pine Plantations. Croat. j. for. eng. 35(1): 63-71.

- Košir, B., 2008A: Modelling Stand Damages and Comparison of Two Harvesting Systems. Croat. j. for. eng. 29(1): 5-14.

- Košir, B., 2008B: Damage to Young Forest Due to Harvesting in Shelterwood Systems. Croat. j. for. eng. 29(2): 141-153.
- Krč, J., Vranešič, U., Košir, B., 2015: Comparison of Mechanized and Motor-manual Cutting Operation in Mixed Stands of Southern Slovenia. Šum. list 139(7-8): 351-360.

- Krieg, B., de Wet, P., Olsen, G., McEvan, A., 2010: Ground Based Harvesting Equopment. In: South African Ground Based Harvesting Handbook, Forest Engineering Southern Africa and Institute for Commercial Forestry Research, 1-182.

- Labelle, E.R., Jaeger, D., Poltorak, B.J., 2015: Assessing the Ability of Hardwood and Softwood Brush Mats to Distribute Applied Loads. Croat. j. for. eng. 36(2): 227-242.

- Löffler, H.J., 1984: Terrain classification for forestry. Report TIM/EFC/WP.1/R.51, 24 August 1984, EU Timber Committee and FAO-ILO, 1-55.

- Lubello, D., 2008: A rule based SDSS for integrated forest harvesting planning. $\mathrm{PhD}$ Thesis, Universita degli studi di Padova, Padova, 1-213.

- MacDonald, A. J., 1999: Harvesting Systems and Equipment in British Columbia. FERIC, Handbook No. HB-12, 1-197.

- Marenče, J., 2014: Effect of Transmission Type on Wheel Slip under Overload - Presented on the Example of the AGT 835T Tractors. Croat. j. for. eng. 35(2): 221-231.

- Mastinu, G., Ploechl, M., 2014: Road and Off-Road Vehicle System Dynamics Handbook. CRC Press, Taylor \& Francis Group, 1-1463.

- Mellgren, P. G., 1980: Terrain Classification for Canadian Forestry. Canadian Pulp and Paper Association, 1-13.

- McEwan, A., Brink, M., van Zyl, S., 2013: Guidelines for Difficult Terrain Ground Based Harvesting Operations in South Africa. ICFR Bulletin 02-2013, 1-149.

- Naghdi, R., Solgi, A., 2014: Effects of Skidder Passes and Slope on Soil Disturbance in Two Soil Water Contents. Croat. j. for. eng. 35(1): 73-80.

- Pandur, Z., Poršinsky, T., Šušnjar, M., Zorić, M., Vusić, D., 2014: Gaženje tla pri izvoženju drva forvarderom u sječinama hrasta lužnjaka. Nova meh. šumar. 35: 23-34.

- Pentek, T., Nevečerel, H., Dasović, K., Poršinsky, T., Šušnjar, M., Potočnik, I., 2010: Analiza sekundarne otvorenosti šuma gorskog područja kao podloga za odabir duljine uža vitla. Šum. list 134(5-6): 241-248.

- Petreš, S., 2006: Oštećivanje ponika i pomlatka pri privitlavanju i privlačenju oblovine traktorom LKT $81 \mathrm{~T}$ iz dovršne sječine hrasta lužnjaka. Šum. list 130(3-4): 87-100.

- Poršinsky, T., Krpan, A.P.B., Stankić, I., 2004: Djelotvornost strojne sječe i izrade u sastojinama tvrdih i mekih listača - 4. dio: Okolišna pogodnost strojne sječe u prirodnim sastojinama. Šumarski list.128(11-12): 655-669.

- Poršinsky, T., Horvat, D., 2005: Indeks kotača kao parametar procjene okolišne prihvatliivosti vozila za privlačenje drva. Nova meh. šumar. 26: 25-38.

- Poršinsky, T., M. Ožura, 2006: Oštećivanje dubećih stabala pri izvoženju drva forvarderom. Nova meh. šumar. 27: 41-49.

- Poršinsky, T., Stankić, I., 2006: Okolišna pogodnost forvardera Timberjack 1710B pri izvoženju oblovine iz nizinskih šuma Hrvatske. Glas. šum. pokuse, pos. izd., 5: 589-600.

- Poršinsky, T., Stankić, I., Bosner, A., 2011: Ecoefficient Timber Forwarding Based on Nominal Ground Pressure Analysis. Croat. j. for. eng. 31(1): 345-356. 
- Poršinsky, T., T. Pentek, A. Đuka, 2012: Opisna i namjenska klasifikacija terena za pridobivanje drva i otvaranje šuma. Studija, Šumarski fakultet Sveučilišta u Zagrebu, Zagreb, str. 1-64.

- Poršinsky, T., Šušnjar, M., Đuka, A., 2012: Određivanje faktora raspodjele mase tereta i privlačenja. Nova meh. šumar. 33: 3544.

- Rowan, A. A., 1996: Terrain Classification. British Forestry Commision, Forest Research - Technical Note 16/95, 1-6.

- Sabo, A., 2003: Oštećivanje stabala pri privlačenju drva zglobnim traktorom Timberjack $240 \mathrm{C}$ u prebornim sastojinama. Šum. list 127(7-8): 335-346.

- Sabo, A., Poršinsky, T., 2005: Skidding of Fir Roundwood by Timberjack 240C from Selective Forests of Gorski Kotar. Croat. j. for. eng. 26(1): 13-27.

- Sever, S., 1980: Istraživanje nekih eksploatacijskih parametara traktora kod privlačenja drva. Disertacija, Šumarski fakultet Sveučilišta u Zagrebu, Zagreb, str. 1-301.

- Sever, S., Horvat, D., 1985: Šumski zglobni traktor snage oko 60 kW. Studija, Šumarski fakultet Sveučilišta u Zagrebu, Zagreb, 1-187.

- Sirén, M., J. Hyvönen, H. Surakka, 2015: Tree Damage in Mechanized Uneven-aged Selection Cutting. Croat. j. for. eng. 36(1): 33-42.

- Solgi, A., Naghdi, R., Tsioras, P.A., Nikooy, M., 2015: Soil Compaction and Porosity Changes Caused During the Operation of Timberjack 450C Skidder in Northern Iran. Croat. j. for. eng. 36(2): 217-225.
- Spinelli, R., Magagnotti, N., Di Fulvio, F., Bergström, D., Danelon, M., Alberti, G., 2014: Comparison of Cost Efficiency of Mechanized Fuel Wood Thinning Systems for Hardwood Plantations on Farmland. Croat. j. for. eng. 35(2): 111-123.

- Strandgard, M., Alam, M., Mitchell, R., 2014: Impact of Slope on Productivity of a Self-levelling Processor. Croat. j. for. eng. 35(2): 193-200.

- Suvinen, A., 2006: A GIS-based Simulation Model for Terrain Tractability. Journal of Terramechanics 43(4): 427-449.

- Šušnjar, M., 2005: Istraživanje međusobne ovisnosti značajki tla traktorske vlake i vučne značajke skidera. Disertacija, Šumarski fakultet Sveučilišta u Zagrebu, Zagreb, str. 1-146.

- Šušnjar, M., A. Bosner, T. Poršinsky, 2010: Vučne značajke skidera pri privlačenju drva niz nagib. Nova meh. šumar. 31:3-14.

- Tomašić, Ž., 2012: Razvoj tehnologije i tehničkih sredstava u pridobivanju drva s obzirom na posebnosti šuma i šumarstva u Republici Hrvatskoj. Nova meh. šumar. 33: 53-67.

- Visser, R., Berkett, H., 2015: Effect of terrain steepness on machine slope when harvesting. International Journal of Forest Engineering 26(1): 1-9.

- Visser, R., Stampfer, K, 2015: Expanding Ground-based Harvesting onto Steep Terrain: A Review. Croat. j. for. eng. 36(2): 321-331.

- Vusić, D., 2013: Pogodnost sustava pridobivanja drvne biomase u smrekovoj šumskoj kulturi. Disertacija, Šumarski fakultet Sveučilišta u Zagrebu, 1-174.

- Wong, J.Y., 1989: Terramechanics and off-road vehicles. Elsevier Publications, 1-251.

\section{Summary}

Maneuverability of specialized forestry vehicles is defined by their ability to overcome terrain unevenness during which interaction between vehicle and terrain geometry occurs. Maneuverability, as a segment of vehicle mobility, is defined by: 1) obstacle crossing, 2) vehicle controllability and 3) ride comfort.

Vehicle specifications are determined during design and construction (dimensions, steering and locomotion systems, mass and its distribution on axles etc.) and together affect the level of vehicle maneuverability. Independently of vehicle purpose, many maneuverability parameters (directly connected to operational use) including approach, departure and ramp (break-over) angles as well as clearance radii are known, but their calculation for varying types of vehicles (different construction, purposes etc.) is still vague.

On the example of wheeled cable skidder, this paper deals with approach, ramp (break-over) and departure angles, longitudinal and transversal clearance radii as significant parameters for skidder mobility and maneuverability on uneven forest stands. Considering specific wheeled cable skidder design and construction together with constant relation of dimension characteristics regardless of different manufacturers, expressions for approach, ramp break-over and departure angles, longitudinal and transversal clearance radii are derived.

KEY WORDS: skidder, approach angle, ramp (break-over) angle, departure angle, longitudinal clearance radius, transversal clearance radius 